\title{
The Mind of the Political and Social Animal
}

\author{
NERIJUS STASIULIS \\ Department of Philosophy and Cultural Studies, Faculty of Creative Industries, Vilnius Gediminas Technical University, 1 Trakų Street, \\ 01132 Vilnius \\ Email: nerijus.stasiulis@vgtu.It;nerijaus.stasiulio@gmail.com
}

\begin{abstract}
In this article I present the outline of Filosofija. Sociogija 30(3) the articles of which I see as mainly centering around the issue of Man as placed and interacting within social, cultural and political contexts. However, the discussion of the social or political is generally nourished by metaphysical or epistemological issues or insights. The human mind deals with the fundamental questions concerning human nature, the existence or the metaphysical structure of the world, the status of cognition in general and science/ technology in particular. The articles merge into a choir signalling the inescapably social and political mode of our consciousness.
\end{abstract}

Keywords: analytic philosophy of mind and language, culture, epistemology, social and political philosophy

Principium individuationis may be treasured and may be the grounding principle of all existence, not to mention the political existence in the current West, yet we find ourselves embedded with others in such a fundamental way that we wonder how the chains of social existence which bind one as an individual may at the same time be considered to be one's kernel and essence. The articles of this issue of Filosofija. Sociologija generally deal with situating an individual consciousness or existence in its sociocultural - thus, ethical - or political contexts.

Çağmar describes the tension in Rousseau's philosophy between freedom of the natural man and the chains that society puts upon him. The author resolves this tension by noting that nature in man is not an unchanging one but is malleable with respect to political structures. Rousseau's individualistic view on human nature is not to deny that man is a social and political animal. He sees civilized life in a society as far superior to any 'natural' existence in that a civilized individual's capacities are greatly developed (Rousseau 1968: 64-65); yet, not all kinds of political life are equally good as some of them lead human beings away from perfection which is synonymous with liberty. Çağmar emphasizes the influence of political structure on human nature as the central topic of political debates established by Rousseau.

Płotka also describes the human person as capable of transcending one's individual ego and identifying his goals with the common good of a community. He presents Wojtyła's theory of solidarity (Wojtyła 1979) according to which 'we' is established through acting, participation. 'We' is not a subject separate from individuals who comprise it but is experienced by taking part in a common action with a community. This is not an interpersonal relation 
between many I's and thou's but a togetherness of action wherein my good and the good of the whole community are experience as one. Płotka presents the phenomenological basis of Wojtyla's theory of solidarity.

Sautkin and Philipova emphasize a metaphysical struggle as the basis of politics. By comparing Lenin's and Nietzsche's views, they identify an essential relation between political power and knowledge. For them, philosophy is not merely theorical but also a practical endeavour driven by an ulterior desire to dominate. The authors see philosophy as integrated into social relationships and power structures and therefore able to change the modus operandi of the social and political machine.

Rimkus also sees the scientific mind as partly constructed by its social environment and able to create or recreate the social sphere. He presents his construal of Kant's philosophy whereby the a priori structures of cognition are not developed only at the level of an individual but also at the level of a social environment. The scholar explains why Kantian philosophy needs to accept the notion of intellectual intuition rejected by Kant to be able to account for the social aspect of the a priori conditions of our knowledge.

Petrusenko and Chursinova draw our attention more closely to the ethical, social and cultural aspects of technological and scientific activity and criticize the dominance of the engineering-technical approach. They claim that a philosophical-anthropological approach (see Pavlenko 20018) to technology and science is capable of broadening our understanding and argue in favour of such an approach presented by Dessauer. It provides a fuller perspective without which the solution to moral and legal issues that arise in the context of developing new technologies is unthinkable.

Holub expands on the ethical aspects by emphasizing dignity as the key value in Western culture. He sees it as an extremely important issue in many anthropological, ethical, bioethical and other debates. The author seeks a way to conduct an investigation of this key value that would not be prone to extremes of either subjectivization of dignity (e.g. Szostek 1998) or limiting it to a set of psychological or other empirical qualities (e.g. Kateb 2011). Both the subjective and objective side should complement each other instead of being contradictory.

Ogleznev investigates social interaction in terms of speech acts and argues against Searle (Searle 1969) that an insincere promise is not a speech act. The so-called sincerity condition requires that a speaker who makes a promise to do A intends to do A. Ogleznev maintains that meeting this condition is necessary for a promise to be a true one and draws on the example of polite promises in West African cultures where making a polite promise does not amount to purporting that one intends to do what one is promising to do.

Finally, social relations would not exist if we would not suppose a true existence of other minds and of the external world. Boongaling offers her take on the sceptical problem by proposing a radical reinterpretation of Quinean naturalism and its view on consciousness. She tries to understand consciousness as phenomenal experience that is not reduced to brain states. The author introduces a distinction between non-phenomenal and phenomenal consciousness to be able to retain the subjective component of the former and the objective component of the latter. She employs this and other tools to combat the ghost of scepticism while maintaining Quinean leanings towards naturalism (Quine 1951).

If the principle of individuation is to guide one into scepticism, is the (re)discovery of the political and the social a ray of the true and the real? Or is it not? 


\title{
References
}

1. Kateb, G. 2011. Human Dignity. Cambridge (MA): The Belknap Press of Harvard University Press.

2. Pavlenko, A. 2008. 'The Possibility of Technology. Part III. Technical Project of Friedrich Dessauer', in Historical and Philosophical Yearbook. Moskva: Nauka, 325-352.

3. Rousseau, J. J. 1968. The Social Contract. London: Penguin Press.

4. Quine, W. V. O. 1951. 'Two Dogmas of Empiricism', The Philosophical Review 60: 20-43.

5. Searle, J. 1969. Speech Acts: An Essay in Philosophy of Language. Cambridge, UK: Cambridge University Press.

6. Szostek, A. 1998. Wokol godnosci, prawdy i milosci. Rozwazania etyczne. Lublin: Wydawnictwo Katolickiego Uniwersytetu Lubelskiego.

7. Wojtyła, K. 1979. The Acting Person. Transl. from the Polish by A. Potocki, ed. A.-T. Tymieniecka. Dordrecht: D. Reidel Publishing Company.

NERIJUS STASIULIS

\section{Politinès ir socialinès būtybès sąmonè}

\author{
Santrauka \\ Šio žurnalo numerio straipsnių autoriai analizuoja žmogaus sąveikos su socialiniais, \\ kultūriniais ir politiniais kontekstais temas. Tačiau socialiniai ir politiniai klausimai kyla \\ iš metafizinių arba epistemologinių problemų ir ižzalgų. Žmogaus sąmonè analizuoja \\ pamatinius žmogaus prigimties, pasaulio egzistavimo arba metafizinès struktūros, pa- \\ žinimo apskritai ir mokslo / technologijos klausimus. Remdamiesi autorių ižvalgomis, \\ kurios tarsi turi bendrą vardikli, matome, kad mūsų sąmonè neišvengiamai veikia socia- \\ liniu ir politiniu režimu.
}

Raktažodžiai: analitinè sąmonès ir kalbos filosofija, epistemologija, kultūra, socialinė ir politiné filosofija 